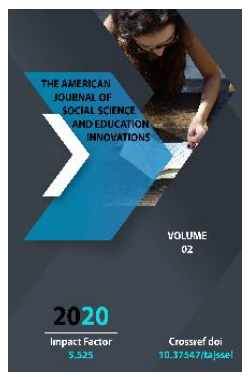

\title{
Types Of Periphrases According To Social-Professional Classification
}

\author{
Ahmadova Umidahon Shavkat Kizi \\ Lecturer, Department Of Uzbek Linguistics, Bukhara State University, Uzbekistan
}

Journal Website:

http://usajournalshub.c

om/index,php/tajssei

Copyright: Original

content from this work

may be used under the

terms of the creative

commons attributes

4.0 licence.

\section{ABSTRACT}

The article provides information on the types of periphrases according to the social-professional classification. The importance of socially occupational classification of periphrases is widely elucidated. it also provides information on the types of classification and its place in linguistics.

\section{KEYWORDS}

Social-professional classification, periphrases, figurative expression, linguistic terms, peasant speech paraphrases.

\section{INTRODUCTION}

There are many different professions in the world, each of which uses its own tools, terms and professionalism, language and speech units that are related to the essence of the profession. For example, a farmer's main tool is a hoe, and a carpenter's axe, saw, the surgeon's knife, the butcher's knife, the ax, the tailor's needle, thread. The farmer builds a unique garden on the bare ground with a hoe, creating beauty. If his skill is not enough, he will die for the life of the earth. If the hoe is not sharp, if the farmer himself has not received the hadith of beating the hoe, the monkeys will sweep over the condition of both the golden soil and the raw farmer. The same can be said about other professions. 
It should be noted that the representatives of each industry, professionals, and social groups have their own paraphrases, along with the terms "identifying" the speech. For example, farmers, artisans, ranchers, medical workers, educators, journalists, religious figures, creators, builders, scientists, speech paraphrases, and so on.

\section{MATERIALS AND METHODS}

Periphrasis is actually a Greek word (paraphrasis), which is used in linguistics, including Uzbek linguistics, to mean "figurative expression." In A. Khodzhiev's "Explanatory Dictionary of Linguistic Terms": "An object is a stylistic device that expresses an event not in its own name, but in a figurative way through a certain context, a characteristic feature of the situation. For example, the queen of the field, (corn) "[3,67]. The linguist R. Kungurov, who interpreted the periphrasis as one of the types of nomads, wrote in his 1983 book "Stylistics of the Uzbek language": "... it is called periphrasis to describe people in different words or figurative expressions without directly saying their names or the names of other objects. This term is also called periphrase, paraphras, paraphrase"'[2], in the researches of M.Mirtojiev: ... In a compound that has the status of a periphrasis, although there is a semantic redistribution, there is no syntactic redistribution "[1]. Certain aspects of the topic of periphrasis have been studied in the world, the world, Uzbek linguistics, and we focus on the socio-professional aspects.

\section{RESULT AND DISCUSSION}

We consider it important to distinguish two aspects when considering the types of periphrases according to the socialprofessional classification. The first is periphrasis about a particular social object, and the second is periphrasis, which is widely or separately used in the speech of representatives of social professions, professions, fields. For example, while health guards - if doctors say about periphrasis, real adrenaline is a professional periphrasis that means healing.

Peasant speech paraphrases. When we say farmer, we mean endless fields, gardens, various delicacies on our table, weddings, happy days, full life. We all know how hard and honorable the work of this industry is, and how sweet and sweet the bread is. It is no coincidence that the great thinker Alisher Navoi praised the services of hardworking farmers, saying that "the fullness and joy of the people of the world is, first of all, the work of selfless people who sow seeds in the ground and cultivate priceless delicacies." We observe the use of colorful periphrasis in relation to the owners of this industry, their activities, sometimes tools, the products they grow.

In particular, the paraphrases of the word Farmer: Our main task is to glorify the work of agricultural workers, who are the creators of our livelihood, to raise the development of the industry to a new level (Internet headline); ... In this sense, it is no exaggeration to say that the farmer is a strong pillar of life, a solid foundation of life. (Sh.Mirziyoev) [4]; We do not always remember that the table of our people is filled with the fruitful work of our farmers, the skin of the forehead. (From an Internet article); In order to achieve food abundance and security in our country, the faithful owner of the fields works day and night and contributes to the development of the country by growing melons (from the speech of "Diyor 24", Dilnoza Urinova); If we look at the results of the work of field workers 
in our country, who have been working tirelessly since early autumn to grow grain, for this year's harvest, we can see that the efforts in this direction are becoming more purposeful ("Akhborot", Bakhtiyor Mamajonov).

Instead of the word farmer, he uses dozens of paraphrases, such as the creator of our livelihood, a strong pillar of life, a solid pillar of life, trampled on the ground, a faithful owner of the fields, a field laborer leads to the conclusion.

When talking about the paraphrases of artisan speech, let us first dwell a little on the term artisan. Naturally, the more and more diverse the types of crafts, the more and more varied the periphrases used about crafts, craft appearances, craft products, or in the speech of craftsmen. For example, periphrasis related to embroidery: The art of embroidery is the immortal value of our people (Internet title); The most ancient and common type of practical ornament inherited from our Piru wealthy grandmothers is embroidery. The delicate fingers of the girls, who are dying for each layer of silk and connecting their feelings with the beauty of beautiful flowers, really create a miracle (http://uza.uz).

Periphrases of gold embroidery: Dice masters create miracles (Newspaper headline); Gold embroidery is a branch of applied art in which embroidery is made of dice (gold and silver), thread, fine wire, silk (https://handicraftman.uz); Master craftsman B.Jumaev explained goldsmithing as a "delicate taste" through a master class. (https://handicraftman.uz).; During the years of independence, the art of Bukhara gold embroidery was revived like a parrot out of fire. (Jewelry of Bukhara handicrafts, p. 14); She is a momomeros profession - goldsmith.
She has participated in many competitions with her unique goldsmithing and sewing work. (http://uza.uz/mohir_zardo'z). Cooking periphrases: - You will learn the secret of these dishes from the sultan of the kitchen, my dear, - said the girl cheerfully (from the newspaper "Darakchi"); Bahriddin Chustiy: cooking is a men's profession (Internet); Only when the food, which is the product of the chef's creativity, enters the national menu, it becomes a real product of creativity (https / bahriddin-chustiy). Baking Periphrases: What We Know and Do Not Know About the Miracle of the Fire or the Tandoor... (Mirror of Justice, 2014. № 38); In fact, the portrait is a living shadow of this person and we try to make it as natural as possible. (From the speech of craftsman F.U. Temirov, 6.02.2020).; Through images created using paints of different colors, we convey the way of life of kings, historical figures, the artistic interpretation of historical truths with a miracle of vivid small dimensions (from the speech of the craftsman F.U. Temirov, 6.02.2020); Bukhara wood carving is one of the most popular types of applied art in Bukhara. (Jewelry of Bukhara handicrafts, 28-p).

The immortal value of our people in the given texts (embroidery), the type of practical decoration (embroidery), the type of art (embroidery), the type of bird copy (embroidery), the type of decorative art (embroidery); dice masters (goldsmiths), ornamental field (goldsmithing), fine craftsmanship (goldsmithing), skillful master (qo'li gul) (goldsmiths), real delicacy patterns (goldsmiths), parrot out of fire, fireflies (art of goldsmithing), momomeros profession (goldsmithing); kitchen sultan (chef), kitchen owner (chef), table wizards (chefs), product of the chef's creativity (food), men's profession (cooking), ancient profession (cooking); liver fire miracle (burner), clean 
workplace (bakery), burner master (baker), dough master (baker), creators of the sun piece (bakers), the grace of our table (bread), the honorable profession (baking), the blessing that awakens the morning (bread), human sustenance (bread), as well as the art of seeing the world (miniature), the miracle of small dimensions (miniature), the living shadow of man (portrait), the king of tourists station (hotel), the art of mysterious patterns (wood carving), the art of royal narration (miniature), and so on.

Periphrases of cattle speech. We are convinced that the paraphrases used in relation to the figurative expression of any concept, idea and the content of the text in their own words are also actively used in the speech of animal husbandry. Livestock is an integral part of agriculture and plays a special role in the national economy. Livestock produces milk, meat and eggs, which are essential human food. Livestock and poultry wastes play an invaluable role in increasing soil fertility as a local fertilizer [5].

Periphrases associated with horse or horsemanship are distinguished by their emotionality, expressiveness, and imagery. In particular, the horse is the companion of the young man (Proverbs); The white vulture is a symbol of happiness, and devotion to its owner is a rare trait in other animals. (From the speech of U. Rajabov); Livestock, which is one of the sources of prosperity, also has 808 head of cattle and 1393 head of small cattle on nineteen farms specializing in animal husbandry in Kagan district. ("Light of Justice", 2009. №10) .; Milk is a product that promotes humanity (Internet headline); Cheese is a nutritious product. The general condition of the body, in particular, improves brain function, protects teeth from caries, keeps blood pressure in check. Eating cheese is also beneficial in cases of insomnia and stress. (https://darakchi.uz).

Periphrases of speech of medical staff. We observe that there are specific periphrases in the speech of representatives of this field, which strives to protect human health. First of all, we observe the use of periphrases in relation to the representatives of the field, such as health guards, white-collar workers, Hippocrates, healers, followers of Ibn Sina (doctors). We will try to prove the medical periphrasis in our language, which is a unique, beautiful, silent, incomparable treasure, with the examples given below. For example, I attended the conference with a presentation on the contribution of medieval Eastern scholars to the development of medicine. I have studied with great interest the scientific heritage of such scholars as Abu Ali ibn Sino, Abu Rayhan Beruni, Mirzo Ulugbek, Alisher Navoi, and the work of Abu Ali ibn Sino, the sultan of medical science, who made an invaluable contribution to the development of world medicine, serves as an eternal fountain in educational institutions. (From a speech by Barbara Potrata, a researcher at the University of Cambridge Forum on Central Asia (UK); Abu Ali ibn Sino, the ancestor of physicians, writes about the treatment of some diseases with nuts. (Aytboev D. Motivation in prefaces denoting specific individuals. TAT. 2007, № 4).; While overcoming the disease of Covid 19 requires strong will and patience from our people, as the piri of doctors Abu Ali ibn Sino said, we can achieve positive results only if we first practice peace of mind (from the speech of Nurse Iroda Elnazarova); Thanks to the devotees in white coats, we have recovered today, and we also thank the President of our country Shavkat Mirziyoyev. (From the program "Information 24", 10.04.2020). 
Periphrases of pedagogical speech. It is no exaggeration to say that teachers are at the top of the list of professionals whose main weapon is speech. No matter what science teacher you are, a teacher's speech needs to be fluent, simple, clear, and understandable enough to reach the listener. After all, no matter how deep and high the knowledge of such a teacher is, if he does not use the language skills skillfully or acquires true cultural speech skills, the hours allotted for the lesson will be a torment for him and the learner. However, the ability and skill to compose a thorough, concise and fluent speech in the language of instruction is equally important for both a mathematics, physics, chemistry or biology teacher and a mother tongue teacher. The teacher's clear cultural speech should arouse admiration and admiration in the student, be an example to him, and at the same time serve as the most convenient means for the subject to be easily mastered by the student. Naturally, one of the means of speech that enriches teachereducator speech is periphrases. Periphrases of pedagogical speech are also unique, usually in relation to our teachers, educators-educators of a harmoniously developed generation (teachers), future builders (teachers), engineer of the human spirit (educator), gardener of science garden (teacher), the face of the nation (pedagogue), a number of periphrasis are used, thus making the work of these honorable and hard-working professionals somewhat recognized. We will try to look at some examples of educator speech paraphrases. In particular, the selfless work of teachers, who are the creators of the future in the upbringing of a harmoniously developed generation, is bearing fruit today. (Uzbekistan TV channel, from the Akhborot program, September 27, 2015); The greatest school in the world is teaching, and the most honorable profession is teaching and coaching
(I. Karimov); Teachers are great and dear people who introduced us to black and white, good and bad, taught us to write words such as "Parents", "Fatherland", "Goodness", "Faith", "Islam" with a pen in our hands for the first time. (https://www.mehrob.uz). Examples show that when periphrases of the word teacher is used, such as future builders, great and dear ones, gardeners of the garden of enlightenment, traveling star, great responsible person, great person, educators, devotees of education, etc., the greatest honor of the teaching profession is status, high career, honorable road periphrasis are applied.

Periphrases of press speech. We observe that the periphrasis is used more and more in the press and press speech, or in relation to them, as a migration with a stylistic dye that provides the color, expressiveness, melody, and appeal of the language. For example, although the term "Fourth Power" is a lyrical term that describes the extent to which the press can influence public opinion in society, it has the right to draw the attention of every citizen to the political and social process in society. (https://www.xabar.uz/) ; Over the past three years, Uzbekistan has created a legal framework and ample opportunities for freedom of speech, comprehensive development of the media, freedom of movement and creativity of journalists and bloggers. We will continue to create all conditions for the representatives of the "fourth society" to act freely and impartially, to openly cover the rapid reforms taking place in our country for our people and the international community (from the petition. 25.01.2020); Who would like other journalists from other countries to interpret our internal problems in their own way, when we have so many talented journalists? (Https://www.xabar.uz/); "It's our job to 
answer the journalist's question and help him solve his problems," he said. (http://zarnews.uz/).; The newspaper is a hot oven. Remember that you are facing fire. (A. Qahhor. Sinchalak, p. 73). Among the paraphrases of the press speech are the fourth power, the fourth society, the operative sphere, the subtle sphere (press), the subtle sphere, the subterranean sphere, the people's voice (journalists), the broadcaster, the true devotee of his profession (press), the hot oven, the face of society, the heart of society, serial publication, new source of information, reliable source of information (newspaper), periodical (magazine), etc. are most actively used.

The paraphrases of the speeches of the representatives of the religious sphere are mainly related to Islam, the holy book of Islam, the Holy Qur'an, its verses, suras, hadiths, prophets, saints and prophets. It should be noted that the periphrases of religious speech in our language are also very numerous and colorful. We found it necessary to be content with the examples of religious paraphrases given in Nosiriddin Rabguzi's "Qissasi Rabguzi". These are: The pride of the world is Muhammad (peace and blessings of Allaah be upon him), the beloved and prophet of Allaah is Muhammad (peace and blessings of Allaah be upon him), the kingdom of God is the heart, the good is Allah, the angel of death is Azrael, the great sin is murder, eternal torment - torment of the hereafter, messenger of god - Ibrahim, good guarantor Allah, good helper - Allah, friend of Allah Ibrahim, saint and ruler - Allah, the best of all creatures - Adam, the ancient book - the Qur'an, the open enemy - the devil, the master of all beings - Allah, the munis of the lonely Allah, the companion of the strangers - Allah, the merciful of the merciful - Allah, the heir of the root of prophecy - Yusuf, The seal of bliss is Yusuf, the reflection of the angel on earth is Yusuf, the friend of Allah is the believers, the exhortation to the whole world is the Qur'an, the owner of the cabbage is Allah, the abode of the angels is heaven, the abode of the jinn is the earth, the hasty creature is human, the key to Allah's treasures is Rahman the garment is greatness, the cloak of Allah is greatness, and etc. It can be observed that the units chosen by the representatives of the religious sphere as the most periphrastic object among the paraphrases of speech are the words Allah, Qur'an, Muhammad s.a.v., heaven, hell, doomsday.

Periphrases of creative speech. When we say creative, we mean, first of all, writers and poets. In fact, the creator (creation-Arabic word + kor (Persian word) is the creator, inventor. Any industry or front will have its own creators. goldsmiths, seamstresses, hairdressers, can be the owners of all the industries, professions, activities that exist in the world.

So far no one was able to send in the perfect solution, which is not strange. Experts generally say: "Creativity is the ability to deviate from accepted thinking habits and create and find new original ideas to successfully solve problems in a non-standard way. It is about looking at problems from the other side and solving them in a unique way. Creative thinking is revolutionary and creative thinking that is constructive in nature. "[6] After all, creativity is important in business, science, culture, art, politics, in short, in all aspects of life where competition is evolving. It is important to remember that any creativity must have a personal (positive) meaning.

We will try to interpret them in a general way, giving examples of general and individual paraphrases used in relation to creators. In 
particular, the owners of the brush - artists: The resolution of the President of the Republic of Uzbekistan dated April 21, 2020 "On additional measures to further increase the efficiency of the fine and applied arts" provides ample opportunities for further development of fine arts, the owners of the brush, masters and crafts will undoubtedly open up new prospects on the path to creation. (https://uza.uz); calligraphers: In the East, the letters of calligraphers, in addition to the expression of meaning, excited and gave aesthetic pleasure. Therefore, each letter was considered a miracle of art, and the calligraphers were considered masters of fine art. (https://uza.uz); Masters of classical rhythm - artists: At the festival, masters of classical maqom performed samples of "Shashmaqom", which is our priceless heritage. (https://uza.uz); unique poet - Sida Zunnunova: The beginning of the TV series "Sabru sadoqat" dedicated to the life of the Hero of Uzbekistan, People's Writer, Said Ahmad and his beloved wife, unique poet Sida Zunnunova. (“Postda”, 2020. № 21); A symbol of fidelity and devotion - Zulfiya Khanim: Zulfiya Israilova is an ordinary Uzbek girl. He is sealed in hearts as a symbol of fidelity and devotion. ("Teacher of Bukhara", 2015. № 4); charming poet-Hamid Olimjon: Among them, especially the work of the charming poet Hamid Olimjon has a strong place in the hearts of thousands of fans of literature. (I.Karimov. Free and prosperous homeland, free and prosperous life - our ultimate goal, p. 509).

As periphrases of the builders' speeches, it is appropriate to mention the following: Master builders, architects and designers, representatives of contractors, labor veterans and dedicated professionals of the industry were invited to the event... It was noted that today, due to the efforts to develop the industry, the construction industry has become one of the most important sectors in the modernization and diversification of the national economy, improving the welfare of the population. (http://uza.uz/).; As a result of large-scale reforms, this multidisciplinary sector, which has a strong legal and regulatory, material and technical base, human resources, has become one of the locomotives of our development. (Http://uza.uz/); ... due to many years of fruitful work, ... great services in the construction of modern buildings and structures, radical transformation of our cities and villages, as well as active participation in the implementation of state programs in this area, builders in all regions of the country were awarded by the President. (http://uza.uz/).

It should be noted that the types of periphrases according to the socialprofessional classification of farmers, artisans, herders, health workers, educators, journalists, representatives of the religious sphere, artists, etc. or the builders do not end with speech paraphrases. This line can be continued in the analysis of speech paraphrases of dozens of industries, professions, such as scientists, architects, tailors, salesmen, butchers, cooks, computer scientists. The most relevant aspect is that periphrases are a methodological tool that beautifies the speech of all industry representatives.

\section{REFERENCES}

1. Mirtojiev M. Lexicology and lexicography of the Uzbek language. - Tashkent, 2000. $-P .42$;

2. Mirtojiev MM Modern Uzbek literary language. - Tashkent, 2007. -P.185.

3. Kungurov R. Stylistics of the Uzbek language. -Tashkent, 1983. - P. 95. 
4. Hojiev A. Annotated Dictionary of Linguistic Terms. - Tashkent, 1985. - p. 67.

5. http://uza.uz Speech of the President of the Republic of Uzbekistan Shavkat Mirziyoyev at the solemn ceremony dedicated to the Day of Agricultural Workers.- 09.12.2017.

6. https://agronet.uz/category/chorvachilik/ uz.delachieve.com/ljodkorlik nima?

6. Harmoniously developed generation is the basis of development of Uzbekistan. T .: Sharq 1997-64 p.

7. N.P.Anikeeva. Spiritual environment in the community T .: "Teacher" 1993. 256 p.

8. Methods of educational work. // Handbook for pedagogical institutes (edited by L. I. Ruvinsky). - T .: Teacher, 1991. $-376 \mathrm{p}$.

9. There is no future without historical memory. // "Dialogue", 1998, issue 5.

10. Tolipov O., Usmonbaeva M. Pedagogical technology: theory and practice.- $\mathrm{T}$.: Science, 2005, - 206 p. 